\title{
Variation of Mercury Contamination in Chicks of Little Tern Sterna albifrons in Southwest Europe: Brood, Age, and Colony Related Effects
}

\author{
P. C. Tavares, ${ }^{1, *}$ L. R. Monteiro, ${ }^{1, * *}$ R. J. Lopes, ${ }^{2}$ M. E. Pereira, ${ }^{3}$ A. C. Duarte, ${ }^{3}$ \\ R. W. Furness ${ }^{4}$ \\ 1 IMAR, DOP, University of Azores, Cais Sta Cruz, 9901-862 Horta, Portugal \\ 2 IMAR, University of Coimbra, 3004-517 Coimbra, Portugal \\ 3 Department of Chemistry, University of Aveiro, 3810-193 Aveiro, Portugal \\ 4 Ornithology Group, Institute of Biomedical and Life Science, Graham Kerr Building, \\ University of Glasgow, Glasgow G12 8QQ, United Kingdom \\ Received: 2 December 2003/Accepted: 6 October 2004
}

Little Tern Sterna albifrons largely uses coastal wetlands with shallow water where small fish can be easily found (Cramp and Simmons 1983). Diet is dominated by small fish but it can also take some invertebrates namely crustaceans or insects. Chicks are semi-nidifugous and are fed by both parents (Cramp and Simmons 1983). In the last decade the species has undergone marked declines in several areas, and most studies have concentrated efforts on the factors influencing breeding success (Holloway 1993) also in saltpans (Catry et al. 2004). Saltpans are characterized by the occurrence of low water levels, high salinity values and drying periods, but water level can be manipulated to provide protection for eggs and nestlings, and to ensure food availability (Britton and Johnson 1987). Portuguese saltpans have been highly affected by human pressure that has caused habitat disturbance (Rufino \& Neves 1992). Several anthropogenic pollution sources have been identified in Portuguese wetland areas, and high mercury concentrations have been observed in Tagus estuary (Figueres et al. 1985) and Aveiro coastal lagoon (Pereira et al. 1998). Mercury is a highly toxic heavy metal, it bioamplifies in the food web and seabirds represent good bioindicators of mercury pollution (Monteiro and Furness 1995). Feathers represent the major elimination pathway for accumulated mercury in soft tissues, mercury levels in feather correlate with body burdens (Furness et al. 1986) and mercury in feathers is almost entirely in the form of methyl-mercury (Thompson et al. $1989 \mathrm{a}, \mathrm{b})$. The study of mercury dynamics in chicks revealed several advantages in the study of mercury contamination (Lewis and Furness 1991, Monteiro and Furness 2001), and the value of chick feathers has been demonstrated in particular (Becker et al. 1993b). Because chicks are confined to a limited area during a period of time, their contamination can be easily accessed and related with environment. Mercury contamination has been monitored for Little Terns breeding in the western Baltic Sea (Thyen et al. 2000) but no data have been reported for the species contamination in other areas. Intra-specific variation for Little Tern chicks was studied in the present work. Age, brood and colony related effects are discussed here in particular.

\section{MATERIALS AND METHODS}

Several saltpans of south-west Europe wetlands Sado estuary, Tagus estuary, Aveiro coastal lagoon were included in the study area (Figure 1). Body feathers

\footnotetext{
*Present address: R. Camara Pestana 7-3 D-Pragal 2800 Almada, Portugal

**L. R. Monteiro (1962-1999)

Correspondence to: P. C. Tavares
} 
were sampled from live Little Tern chicks during 2000, 2001 and 2002 breeding periods. Blood samples were also collected from large chicks during 2001 and 2002 simultaneously to feather collection. Feathers were kept in polyethylene bags. Blood were preserved in $1 \mathrm{ml}$ tubes at $-20^{\circ} \mathrm{C}$. The standard biometric variables 'Head plus Bill' length and Wing length were measured (Svensson 1992). Body weight was measured using a spring balance reading to the nearest gram. Wing length was considered as the main biometric variable (Norman 1992) and chicks were classified into two arbitrary size classes, 'small' chicks (Wing length $<70 \mathrm{~mm}$ ) and 'large' chicks (Wing length $>70 \mathrm{~mm}$ ). Samples were analysed for total mercury concentration by Cold Vapour Atomic Absorption Spectroscopy. Samples were digested in a water bath at $70{ }^{\circ} \mathrm{C}$ for 6 hours by addition of concentrated $\mathrm{H}_{2} \mathrm{SO}_{4}$. $\mathrm{KMnO} 45 \%$ was added and the solution kept at $70{ }^{\circ} \mathrm{C}$ for another 2 hours. The $\mathrm{KMnO}_{4}$ in excess was reduced with $\mathrm{NH} 2 \mathrm{OH} . \mathrm{HCl}$ $20 \%$. Reproducibility was assessed by successive measurements with the same sample (Miller and Miller 2000). Relative standard deviations of around 5\% were found. Accuracy of the method was monitored analysing the reference material TORT-2 (NRCC, Canada) and it was within $10 \%$ of the reference value. The limit of detection defined as twice the standard deviation of triplicate analysis at very low concentrations (Saltzman et al. 1983) was $0.01 \mu \mathrm{g} \mathrm{Hg}$. The goodness of fit to Normal Distribution (Kolmogorov-Smirnov one-sample tests) and the homogeneity of variance assumption were checked. Parametric tests were applied (Zar 1984). All statistical tests used the Statistica software package StatSoft 1995 and were performed with $5 \%$ as threshold for significance.

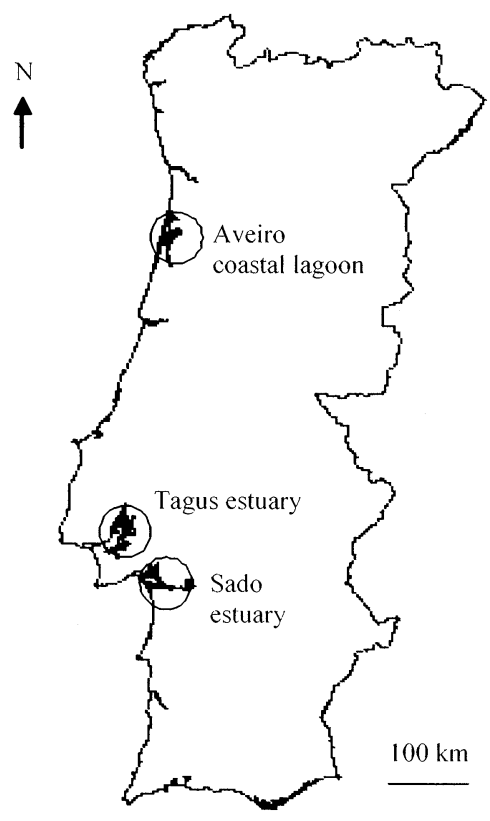

Figure 1. Portuguese coastal wetlands in the study area. 


\section{RESULTS AND DISCUSSION}

Linear measurements of chick size showed significant positive correlation between biometric variables 'Head plus Bill' and Wing length (Pearson $r=0.89$, $\mathrm{p}<0.05$ ). Considering relationships between these variables and the weight both showed approximately linear relationships rather than cubic ones. Significant positive correlation was observed for 'Head plus Bill' length with weight (Pearson $\mathrm{r}=0.96, \mathrm{p}<0.05$ ) and Wing length with weight (Pearson $\mathrm{r}=0.93, \mathrm{p}<0.05$ ). Significant negative correlations were observed between 'Head plus Bill' length and total mercury concentration in feather for A. Vedros in 2000 breeding period (Pearson $\mathrm{r}=-0.65, \mathrm{p}<0.05$ ), for Vaia (Pearson $\mathrm{r}=-0.65, \mathrm{p}<0.05$ ), Mourisca (Pearson $r=-0.63, p<0.05$ ) and Rosario (Pearson $r=-0.86, p<0.05$ ) in 2001 period, and for Mourisca (Pearson $r=-0.70, p<0.05$ ) and Vau (Pearson $r=-0.46$, $\mathrm{p}<0.05)$ in 2002 period. Significant negative correlations were also observed between Wing length and mercury levels in feather for Rosario (Pearson $r=-0.50$, $\mathrm{p}<0.05$ ) in 2001 period, and for Mourisca (Pearson $r=-0.54, p<0.05$ ) and Vau (Pearson $r=-0.49, p<0.05$ ) in 2002 period. Significant positive correlation was observed between blood and feather for mercury levels (Pearson $r=0.75$, $\mathrm{p}<0.001$ ). Mercury levels were respectively $0.17 \pm 0.08$ and $4.07 \pm 1.42 \mu \mathrm{g} \mathrm{g}^{-1}$ f.w. Mercury levels in blood were not correlated with biometry (Pearson $r, p>0.05$ ).

Table 1. Total mercury concentration ( $\mu \mathrm{g} \mathrm{g}^{-1}$ f.w.) in feather of Little Tern chicks from 'small' and 'large' size classes in different sites and years.

\begin{tabular}{|c|c|c|c|c|c|c|}
\hline \multirow[b]{2}{*}{ Site } & \multicolumn{2}{|c|}{2000} & \multicolumn{2}{|c|}{2001} & \multicolumn{2}{|c|}{2002} \\
\hline & 'small' & 'large' & 'small' & 'large' & 'small' & 'large' \\
\hline Vaia ${ }^{\prime}$ & $\begin{array}{c}5.2 \pm 1.3 \\
n=3\end{array}$ & $\begin{array}{c}4.0 \pm 1.1 \\
n=13\end{array}$ & $\begin{array}{c}5.4 \pm 1.5 \\
n=5\end{array}$ & $\begin{array}{c}4.3 \pm 1.1 \\
n=8\end{array}$ & & $\begin{array}{c}3.9 \pm 0.9 \\
n=9\end{array}$ \\
\hline Mourisca' & & $-1-5$ & $\begin{array}{c}4.0 \pm 0.2 \\
n=3\end{array}$ & $\begin{array}{c}3.4 \pm 0.1 \\
n=10\end{array}$ & $\begin{array}{c}10.8 \pm 8.2 \\
n=13\end{array}$ & $\begin{array}{c}4.1 \pm 1.0 \\
n=15\end{array}$ \\
\hline P. Torto & & & & & $\begin{array}{c}11.6 \pm 6.0 \\
n=4\end{array}$ & $\begin{array}{c}1.9 \pm 0.1 \\
n=3\end{array}$ \\
\hline P. Sado' & & & & & $\begin{array}{c}5.4 \pm 0.3 \\
n=3\end{array}$ & $\begin{array}{c}2.2 \pm 0.2 \\
\mathrm{n}=3\end{array}$ \\
\hline Mitrena' & & & & & $\begin{array}{c}7.9 \pm 5.1 \\
n=4\end{array}$ & $\begin{array}{c}5.0 \pm 0.9 \\
n=7\end{array}$ \\
\hline Rosario $^{2}$ & & & $\begin{array}{c}5.8 \pm 1.5 \\
n=7\end{array}$ & $\begin{array}{c}3.1 \pm 0.5 \\
n=11\end{array}$ & $\begin{array}{c}10.4 \pm 1.9 \\
n=3\end{array}$ & $\begin{array}{c}2.7 \pm 0.9 \\
n=3\end{array}$ \\
\hline $\mathrm{Vau}^{2}$ & & & & & $\begin{array}{c}7.0 \pm 0.9 \\
n=5\end{array}$ & $\begin{array}{c}5.5 \pm 1.1 \\
n=8\end{array}$ \\
\hline A.Vedros ${ }^{2}$ & $\begin{array}{c}6.7 \pm 3.5 \\
n=9\end{array}$ & $\begin{array}{c}4.2 \pm 1.2 \\
n=4\end{array}$ & & & & \\
\hline $\mathrm{Passa}^{3}$ & & & & & & $\begin{array}{c}4.9 \pm 2.4 \\
n=15\end{array}$ \\
\hline
\end{tabular}

Legend: 'Sado estuary, ${ }^{2}$ Tagus estuary, ${ }^{3}$ Aveiro coastal lagoon. Values refer to average, standard deviation and sample size. 
Significant differences were found for total mercury concentration in feather between 'small' and 'large' chicks for Rosario in 2001 ( $t$ student test, $t=6.21$, $\mathrm{p}<0.05$ ) and for P.Torto during 2002 ( $t$ test, $t=4.37, \mathrm{p}<0.05$ ), with higher levels in 'small' chicks (Table 1). When analyzed separately for each size class, a significant negative correlation was observed between 'Head plus Bill' length and mercury concentration in feather (Pearson $\mathrm{r}=-0.81, \mathrm{p}<0.05$ ) for 'small' chicks in Rosario in 2001 breeding period. No significant differences were observed between broods of 'large' chicks in the studied colonies (one-way ANOVA, $p>0.05$ ), but significant differences were found between broods of 'small' chicks in Mourisca colony in 2002 period (one-way ANOVA, $F(3,4)=7.53, p<0.05$ ). Mean mercury concentrations in feather varied between 6.1 and $25.1 \mu \mathrm{g} \mathrm{g}^{-1}$ f.w. for broods of 'small' chicks in Mourisca colony (Table 2). Significant differences were observed between 2001 and 2002 for mercury concentration in feather of 'small' chicks in Rosario colony ( $t$ test, $t=-3.8$, df $=8, \mathrm{p}<0.01$ ) and between 2000,2001 and 2002 periods for mercury concentration in feather of 'small' chicks in Vaia colony (one-way ANOVA, $F(2,6)=5.6, p<0.05$ ). Significant variation was observed between colonies for mercury concentration in feather of 'large' chicks during 2001 (one-way ANOVA, F(7,55) = 4.2, p<0.01) and 2002 (one-way ANOVA, F(2,24) $=5.3, \mathrm{p}<0.05$ ) periods. The highest mean mercury value in feather of 'large' chicks was observed for Vau colony in 2002 period (Table 1). No significant differences were found between colonies for 'large' chicks in 2000 period ( $t$ test, $\mathrm{p}>0.05$ ). No significant inter-colony variation was found for mercury concentration in feather of 'small' chicks in 2000 period ( $t$ test, $\mathrm{p}>0.05$ ), and in 2001 or 2002 periods (one-way ANOVA, $\mathrm{p}>0.05$ ).

Table 2. Total mercury concentration ( $\mu \mathrm{g} \mathrm{g}^{-1}$ f.w.) in chick feathers of Little Tern broods in different sites and years.

\begin{tabular}{|c|c|c|c|c|c|}
\hline Brood & $\begin{array}{l}2000 \\
\text { Vaial }^{1}\end{array}$ & $\begin{array}{c}2001 \\
\text { Mourisca' }\end{array}$ & $\begin{array}{c}2001 \\
\text { Rosario }^{2}\end{array}$ & $\begin{array}{c}2002 \\
\cdot \text { Mouriscal }\end{array}$ & $2002 \mathrm{Vau}^{2}$ \\
\hline Brood 1 & $\begin{array}{c}3.9 \pm 0.4 \\
n=3^{b}\end{array}$ & $\begin{array}{c}3.9 \pm 0.1 \\
n=2^{b}\end{array}$ & $\begin{array}{c}3.1 \pm 0.7 \\
n=3^{b}\end{array}$ & $\begin{array}{c}15.7 \pm 4.2 \\
n=3^{a}\end{array}$ & $\begin{array}{c}7.3 \pm 0.2 \\
\mathrm{n}=3^{\mathrm{b}}\end{array}$ \\
\hline Brood 2 & $\begin{array}{c}3.9 \pm 0.4 \\
n=3^{b}\end{array}$ & $\begin{array}{c}3.9 \pm 1.0 \\
n=3\end{array}$ & $\begin{array}{c}2.9 \pm 0.2 \\
n=3^{b}\end{array}$ & $\begin{array}{c}10.8 \pm 1.1 \\
n=3^{a}\end{array}$ & $\begin{array}{c}6.8 \pm 0.7 \\
n=3^{b}\end{array}$ \\
\hline Brood 3 & $\begin{array}{c}4.2 \pm 0.6 \\
n=3^{b}\end{array}$ & $\begin{array}{c}3.1 \pm 0.1 \\
n=3^{b}\end{array}$ & $\begin{array}{c}4.6 \pm 0.2 \\
n=3^{b}\end{array}$ & $\begin{array}{c}25.1 \pm 6.9 \\
n=3^{a}\end{array}$ & $\begin{array}{c}4.3 \pm 0.8 \\
n=3\end{array}$ \\
\hline Brood 4 & & $\begin{array}{c}3.7 \pm 0.4 \\
n=3^{b}\end{array}$ & $\begin{array}{c}2.9 \pm 0.3 \\
n=3^{b}\end{array}$ & $\begin{array}{c}6.1 \pm 0.8 \\
n=2^{a}\end{array}$ & \\
\hline Brood 5 & & $\begin{array}{c}2.7 \pm 0.2 \\
n=2\end{array}$ & $\begin{array}{c}2.9 \pm 0.1 \\
n=3^{b}\end{array}$ & $\begin{array}{c}3.3 \pm 0.2 \\
n=3^{b}\end{array}$ & \\
\hline Brood 6 & & & & $\begin{array}{c}2.8 \pm 0.3 \\
n=3^{b}\end{array}$ & \\
\hline Brood 7 & & & & $\begin{array}{c}4.6 \pm 0.6 \\
n=3^{b}\end{array}$ & \\
\hline
\end{tabular}

Legend: 'Sado estuary, ${ }^{2}$ Tagus estuary, ${ }^{3}$ Aveiro coastal lagoon, ${ }^{\text {ac }}$ small' chicks' ' 'large' chicks. Values refer to average, standard deviation and sample size. 
Intra-specific variation of mercury contamination in chicks can be influenced by a variety of factors such as egg contamination, hatching order or chick age. Chick age has shown to be an important factor since it is highly related to others such as dietary intake, body mass increments and feather growth (Monteiro and Furness 1995). Several patterns were referred in published studies about age related effects. In some cases age did not correlate with mercury contamination (Stewart et al. 1994). In others contamination decreased (Wenzel et al. 1996, Goutner and Furness 1997) or increased (Becker et al. 1993a, Stewart et al. 1997) with age. In the present study mercury levels in feathers were tested for age related effect using 'Head plus Bill' length and Wing length, and significant negative correlations were observed with both variables. Differences observed between size classes confirmed correlations between chick biometry and mercury levels. Age related effect is expected to depend on the balance between mercury inputs by food intake and large body mass increments during chick growth. Although mercury burden can increase in the chick body, its concentration can be reduced by rapid increasing body mass in chicks and that can be referred as a dilution effect (Becker et al. 1994). Little Tern chicks undergo large mass and skeletal increments during a small time period as revealed by the relation between biomery and weight. Fledging period occupies 19-20 days after hatchling (Cramp and Simmons 1983). Large increments observed in chick weight during this period can represent a strong dilution effect which can explain the negative correlations reported in the present study between mercury levels and chick biometry. The present results also showed that brood related effect was not significant for 'large' chicks in Mouriscas and Rosario colonies, which suggested that brood origin is not important for older chicks. On the contrary, mercury levels varied significantly between broods for 'small' chicks in Mouriscas colony which indicated that brood origin can be important for younger chicks. Moreover colony related effect was observed for 'large' chicks. On the other hand no significant variation was observed between colonies for 'small' chicks. Inter-year differences were significant but it was not so well marked as spatial one. Spatial variation has been observed for Black-winged Stilt in these wetlands (Tavares et al. 2004).

We suggested that inter-colony variation for mercury level in older chicks can result from inter-site differences in the environmental contamination. Mercury uptake through food ingestion is usually considered to be the main process determining mercury contamination in fledglings (Becker et al. 1993a,b). Results from brood related variations also seem to indicate that mercury levels in growing chicks became independent of factors such as egg contamination. Other studies have shown that egg contamination represents about $20 \%$ of the female contamination during a limited period before egg laying, and that egg mass represents only $2-8 \%$ of a completely grown chick, which explains why the egg contamination is considered to be a negligible factor in the fledgling contamination (Monteiro and Furness 1995). Instead the mercury uptake, the dilution effect and also the feather growth seem to be the main factors determining mercury concentration in feather for fledglings (Becker et al. 1994, Goutner and Furness 1997). In the present study the mercury uptake entering the chick body did not balance the dilution effect in most colonies. Even when young 
chicks revealed high mercury levels, mercury contamination in old chicks was significantly lower. It was the case of P. Torto colony which revealed the highest mean mercury level in feather for 'small' chicks. On the contrary the proximity to localized pollution sources can enhance mercury loads entering in the chick body that partly balances the dilution effect. Mourisca colony in 2001 and Vaia colony in 2000 and 2001 revealed similar levels between 'small' and 'large' chicks, but the levels in 'small' class remained the lowest. Probably because the mercury inputs were not enough to mask completely the dilution effect as revealed by the negative correlation obtained for age related effect. The well-marked age related effect reported for Little Tern chicks suggested that dilution effect is the main factor determining the mercury contamination in large chicks.

Acknowledgments. Primary financial support was provided by FCT and FSE (Portugal) through the PhD grant and the project PNAT15007/99. Additional funding was provided by IMAR- DOP, RNET, IBLS- U. Glasgow, U. Aveiro.

\section{REFERENCES}

Becker PH, Furness RW, Henning D (1993a) Mercury dynamics in young common tern (Sterna hirundo) chicks from a polluted environment. Ecotoxicology 2:33-40

Becker PH, Furness RW, Henning D (1993b) The Value of chick feathers to assess spatial and inter-specific variation in the mercury contamination of seabirds. Environ Monit Assess 28:255-262

Becker PH, Henning D, Furness RW (1994) Differences in mercury contamination and elimination during feather development in gull and tern broods. Arch Environ Contam Toxicol 27:162-167

Britton RH, Johnson AR (1987) An ecological account of a mediterranean salina: the salina de Giraud, Camargue. Biol Conserv 42:185-230

Catry T, Ramos JA, Catry I, Allen-Revez M, Grade N (2004) Are salinas a suitable alternative breeding habitat for Little Tern Sterna albifrons? Ibis 146:247-257

Cramp S, Simmons KEL (1983) Handbook of the Birds of Europe the Middle East and North Africa. The Birds of the Western Paleartic, vol 3 (Waders to Gulls). Oxford University Press, New York

Figueres G, Martin JM, Meybeck M, Seyler P (1985) A comparative study of mercury contamination in the Tagus Estuary (Portugal) and major french estuaries (Gironde, Loire, Rhône). Estuar Coast Shelf Sci 20:183-203

Furness RW, Muirhead SJ, Woodburn M (1986) Using bird feathers to measure mercury in the environment: Relationships between mercury content and moult. Mar Pollut Bull 17:27-30

Goutner V, Furness RW (1997) Mercury in feathers of Little Egret Egretta garzetta and Night Heron Nycticorax nicticorax chicks and in their prey in the Axios Delta, Greece. Arch Environ Contam Toxicol 32:211-216

Holloway M (1993) The variable breeding success of the little tern Sterna albifrons in south-east India and protective measures needed for its conservation. Biol Conserv 65:1-8 
Lewis SA, Furness RW (1991) Mercury accumulation and excretion in laboratory reared Black-Headed Gull Larus ridibundus chicks. Arch Environ Contam Toxicol 2:316-320

Miller JN, Miller JC (2000) Statistics and chemometrics for analytical chemistry. $4^{\text {th }}$ edition, Prentice Hall, London

Monteiro LR, Furness RW (1995) Seabirds as monitors of mercury in the marine environment. Water Air Soil Pollut 80:851-870

Monteiro LR, Furness RW (2001) Kinetics, dose-response, excretion and toxicity of methylmercury in free-living Cory's Shearwaters chicks. Environ Toxicol Chem 20:1816-1823

Norman D (1992) The growth rate of Little Tern Sterna albifrons chicks. Ring \& Migrat 13:98-102

Pereira ME, Duarte AC, Millward GE, Vale C, Abreu SN (1998) Tidal export of particulate mercury from the most contaminated area of Aveiro's lagoon, Portugal. Sci Tot Environ 213:157-163

Rufino R, Neves R (1992) The effects on wader populations of the conversion of salinas into fish farms. In: Finlayson CM, Hollis GE \& Davis TJ (eds). Managing mediterranean wetlands and their birds. Proc. Symp., Grado, Italy, 1991. IWRB Spec. Publ. 20:177-182

Saltzman BE, Yeager DW, Meiners BG (1983) Reproducibility and quality control in the analysis of biological samples for lead and mercury. American Ind Hyg Assoc Journal 44:263-267

Stewart FM, Thompson DR, Furness RW, Harrison N (1994) Seasonal variation in heavy metal levels in tissues of Common Guillemots, Uria aalgae from Northwest Scotland. Arch Environ Contam Toxicol 27:168-175

Stewart FM, Phillips RA, Catry P, Furness RW (1997) Influence of species, age and diet on mercury concentrations in Shetland seabirds. Mar Ecol Prog Ser $151: 237-244$

Svensson L (1992) Identification guide to european passerines. $4^{\text {th }}$ edition, Vierde druk, Stockholm

Tavares PC, Monteiro LR, Lopes RJ, Correia dos Santos MM, Furness RW (2004) Intra-specific variation of mercury contamination in chicks of Blackwinged Stilt (Himantopus himantopus) in coastal wetlands from southwestern Europe. Bull Environ Contam Toxicol 72:437-444

Thyen S, Becker PH, Behmann H (2000) Organochlorine and mercury contamination of little terns (Sterna albifrons) breeding at the western Baltic Sea, 1978-96. Environ Pollut 108:225-238

Thompson DR, Furness RW (1989a) The chemical form of mercury stored in South Atlantic Seabirds. Environ Pollut 60:305-317

Thompson DR, Furness RW (1989b). Comparison of the levels of total and organic mercury in seabird feathers. Mar Pollut Bull 20(11):577-579

Wenzel C, Adelung D, Theede H (1996) Distribution and age-related changes of trace elements in kittiwake Rissa tridactyla nestlings from an isolated colony in the German Bight, North Sea. Sci Tot Environ 193:13-26

Zar JH (1996) Biostatistical analysis. $3^{\text {rd }}$ edition, Prentice-Hall International Editions, New Jersey 